\title{
Treatment outcomes of using paraosseous clamp and cerclage stabilisation technique in long bone fractures of cats: a retrospective study
}

\author{
İlker ŞEN 1,a, ${ }^{\otimes}$, Mehmet SAĞLAM ${ }^{2, b}$ \\ ${ }^{1}$ Sivas Cumhuriyet University, Faculty of Veterinary Medicine, Department of Surgery, Sivas; ${ }^{2}$ Aksaray University, Faculty of \\ Veterinary Medicine, Department of Surgery, Aksaray, Turkey.

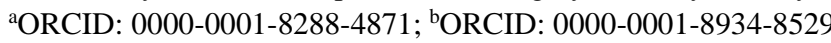 \\ Corresponding author: ilkersenn@yandex.com \\ Received date: 28.02.2020 - Accepted date: 01.07.2020
}

\begin{abstract}
The stabilisation technique of paraosseous clamp and cerclage has become one of the most widely used current techniques because of the easy of applicability and low cost. It is a relatively new method providing rigid fixation in the treatment of fractures, especially those which do not have sufficient cortex resistance and have a wide medullar canal in the period when the long bones of the extremity have not completed development. The technique is based on binding 3 double cerclage wires to each other to form a paracortical belt. The aim of this study was to evaluate the clinical and radiological results of fractures in the extremity long bones of cats treated with the new stabilisation method of paraosseous clamp and cerclage. The study group was formed of 14 cats of various breeds and ages, of both genders, diagnosed with a fracture of the extremity long bone. Clinical and radiographical follow-up examinations were made at 10,30, and 45 days postoperatively. Clinical healing was achieved in 13 cases on postoperative day 45, and those cases could use the affected extremity. A correlation was determined between the functional healing results and low complication rates, including unstable fractures, and it is supported that this technique could be use of this technique in the treatment of long bone fractures. In conclusion, the results of this study demonstrated that the paraosseous clamp and cerclage stabilisation technique can be used as an alternative method in the treatment of long bone fractures, especially in indicated cases.
\end{abstract}

Keywords: Cat, cerclage, fracture, paraosseous clamp, stabilisation.

\section{Kedilerde karşılaşılan ekstremite uzun kemik kırıklarının paraosseöz klemp ve serklaj ile stabilizasyon tekniği kullanılarak sağaltımları üzerine retrospektif bir çalışma}

Özet: Paraosseöz klemp ve serklaj ile stabilizasyon tekniği, kolay uygulanabilirliği ve düşük maliyeti nedeniyle güncel teknikler arasında yer almaya başlamıştır. Ekstremite uzun kemiklerinin kemik gelişiminin tamamlanmadığı dönemde, özellikle korteksin yetersiz direnci ve medullar kanalın geniş olduğu kırıkların sağaltımında rijid fiksasyon sağlayan nispeten yeni bir metottur. Uygulama 3 çift serklaj telinin parakortikal olarak bir kemer oluşturacak şekilde birbirine bağlanması esasına dayanmaktadır. Bu çalışmada, kedilerin ekstremite uzun kemiklerinde oluşan kırıkların yeni bir stabilizasyon yöntemi olan "Paraosseöz klemp ve serklaj ile stabilizasyon tekniği”" kullanılarak sağaltımının klinik ve radyolojik değerlendirme sonuçlarını aktarmak amaçlandı. Çalışma materyalini, klinik ve radyolojik muayeneler sonrasında, ekstremite uzun kemiklerinde kırık belirlenen değişik ırk, yaş ve cinsiyette 14 kedi oluşturdu. Hastaların postoperatif 10, 30 ve 45. gün klinik ve radyografik kontrolleri yapıldı. Postoperatif 45 . günde 13 olguda klinik iyileşmenin sağlandığı ve olguların ilgili ekstremitelerini kullandıkları gözlendi. Stabil olmayan kırıklar da dahil olmak üzere, fonksiyonel iyileşme sonuçları ve düşük komplikasyon oranlarıyla ilişkilendirildiğinde, uzun kemiklerin kırıklarının sağaltımında bu tekniğin kullanımı desteklenmektedir. Sonuç olarak, "Paraosseöz klemp ve serklaj ile stabilizasyon tekniğił”nin, kedilerin ekstremite uzun kemik kırıklarının sağaltımında, özellikle endike olan olgularda alternatif bir yöntem olabileceği kanısına varılmıştır.

Anahtar kelimeler: Kedi, kırık, paraosseöz klemp, serklaj, stabilizasyon.

\section{Introduction}

In the application of non-rigid stabilisation methods, such as intramedullary nailing, major complication rates are extremely high. More rigid fixation techniques, such as external fixator or plate osteosynthesis provide better clinical healing with a major complication rate of $<6 \%$ (5). 
As stabilisation with paraosseous clamp and cerclage is simple to apply and low-cost, veterinary surgeons have started to accept this technique in surgery (5).

This is a new method providing rigid fixation in the treatment of long bone fractures. It is indicated in particular in simple or fragmented diaphyseal fractures. The intact section in both fragments of the fracture must be of a length which can support the required number of double cerclage wires. The method is based on the binding together of 3 double cerclage wires to form a paracortical belt. In a study of two small case series, successful results were reported even in multi-fragmented fractures (3).

The body of the clamps, which are formed with pins or Kirschner wires (K-wires), assists in consolidation of the long axis of the bone by functioning as an extraosseous splint. The transcortical section of the applied pin or Kwire assists in providing rotational stability (10). At the same time, minimal movement is permitted in the fracture line due to the flexibility of the pins. Micro-movement of the fragments triggers callus formation $(1,2)$. The small implant dimensions assist in protecting bone tissue, blood circulation and surrounding soft tissues. Intracorporeal placement of the implant increases implant compatibility of the patient and the risk of the animal injuring itself can be avoided. In addition, the risk of infection, implant loosening and neuromuscular damage is reduced. Postoperative care requirements are at a minimal level, and there is no need for frequent bandage changing and pin cleaning. The costs of surgery and time, which is dependent on the operator's experience, are comparable with other techniques (8).

The advantages of this system are that it can be applied to every size of patient and the implant costs are low, whereas the major disadvantage is that the approach to the operated area is similar to that used in osteosynthesis provided with a plate (9).
The aim of this retrospective study was to present the clinical and radiological evaluation results of long bone fractures in cats treated with new osteosynthesis method that named paraosseous clamp and cerclage stabilisation.

\section{Materials and Methods}

A total of 14 cats of various breeds and ages, of both genders that were diagnosed with a long bone fracture of the extremity as a result of clinical and radiological examinations were included in this study. Information about the animals are presented in Table 1.

In clinical examination of the cases, first a detailed anamnesis was taken from the owner of the animal. In cases with a good general condition, sedation was administered and two-way radiographs were taken in the craniocaudal (Cr-Cd) and mediolateral (ML) positions. In preoperative period, the owners were instructed not to give any food for 8 hours before the operation and no water for 4 hours. As sedation, $80 \mu \mathrm{gr} / \mathrm{kg} \quad(0.08 \quad \mathrm{ml} / \mathrm{kg})$ Medetomidine was administered, followed by a intramuscular injection of $5 \mathrm{mg} / \mathrm{kg}$ Ketamine $\mathrm{HCl}$ to provide general anaesthesia. In the operations, $1.5 \mathrm{~mm} \mathrm{~K}$ wires and $0.5 \mathrm{~mm}$ cerclage wires were used.

Surgical procedure: Using an appropriate approach to the field of operation, the bone fragments were exposed. Two or three K-wires of $1.5 \mathrm{~mm}$ diameter were cut at various lengths, and then shaped in a U-form to be used as the clamp. The bone fragments were brought end to end to provide anatomic alignment. On the lateral, medial, cranial and caudal surfaces of the fragments, transcortical holes were opened as far from the fracture line as possible, K-wires were prepared accordingly the lengths and diameters. The transcortical holes were made perpendicular to the bone long axis on the lateral and cranial surfaces of the humerus, on the cranial and lateral or craniolateral surfaces of the antebrachium, on the cranial,

Table 1. The distribution of breed, age, gender, and fracture localisation of the cases.

\begin{tabular}{|c|c|c|c|c|}
\hline Case no & Age (Year) & Breed & Gender & Lesion \\
\hline 1 & 1 & Domestic cat & q & Tibia \\
\hline 2 & 1,5 & Domestic cat & $\hat{0}$ & Tibia \\
\hline 3 & 2 & Scottish fold & $\hat{0}$ & Radius-ulna \\
\hline 4 & 9 months & Domestic cat & $\hat{0}$ & Femur \\
\hline 5 & 3 & Domestic cat & $\hat{0}$ & Humerus \\
\hline 6 & 10 months & Domestic cat & o & Radius-ulna \\
\hline 7 & 11 months & Ankara & $\hat{o}$ & Radius-ulna \\
\hline 8 & 1 & Domestic cat & $\hat{\sigma}$ & Tibia \\
\hline 9 & 1 & Domestic cat & q & Monteggia \\
\hline 10 & 7 months & Persian & $\hat{o}$ & Tibia \\
\hline 11 & 1 & Domestic cat & $\hat{o}$ & Femur \\
\hline 12 & 8 months & Ankara & q & Monteggia \\
\hline 13 & 2 & Domestic cat & q & Tibia \\
\hline 14 & 2 & Domestic cat & $\hat{o}$ & Radius-ulna \\
\hline
\end{tabular}


lateral and caudolateral surfaces of the femur, and on the medial, craniomedial and caudomedial surfaces of the tibia. The clamps were passed through the transcortical section holes matched with the holes opened appropriate to the dimensions of the clamps previously prepared on the same surfaces. The clamps were temporarily fixed using forceps. The same procedures were repeated for the other planes. Cerclage wires of $0.5 \mathrm{~mm}$ diameter were placed surrounding the clamps. A sufficient number of cerclage wires were applied to provide rigid stabilisation and were tightened. Thus, the fixation of the K-wires to the bone was increased (Figure 1 and Figure 2).

The operation procedure was completed with routine closure of the operated region. Postoperatively, a splint and bandage were applied and analgesia of meloxicam at $0.2 \mathrm{mg} / \mathrm{kg}$ was administered subcutaneously. Clinical and radiographical examinations were applied at 10,30 and 45 days postoperatively.

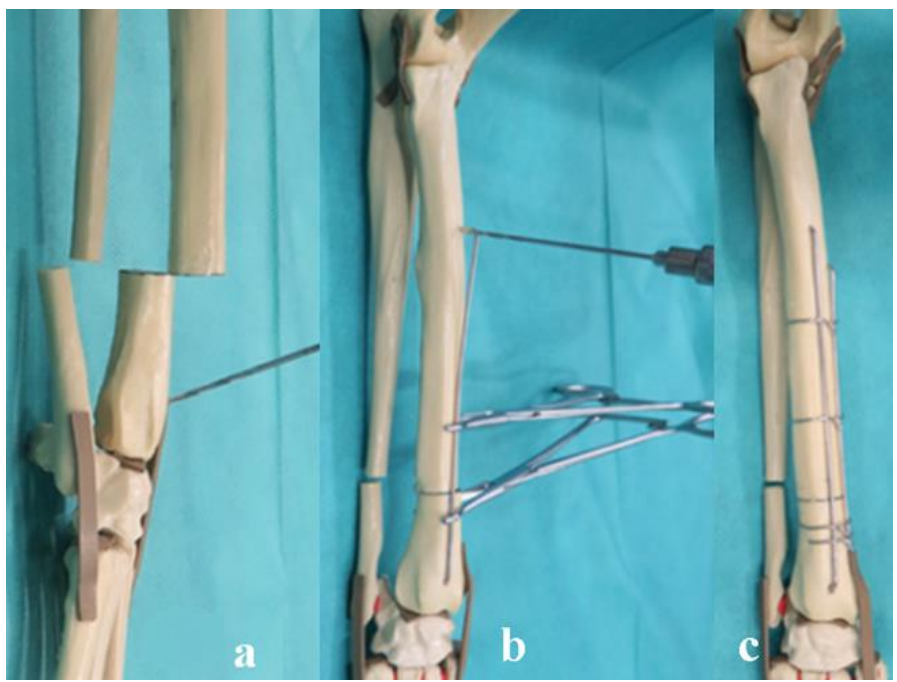

Figure 1. The application principles of the stabilisation technique with paraosseous clamp and cerclage. a) opening the hole on the distal fragment of the radius, b) temporarily fixing the pins to the bone cortex with locking forceps, c) applying the cerclage wires around the clamps. (5)

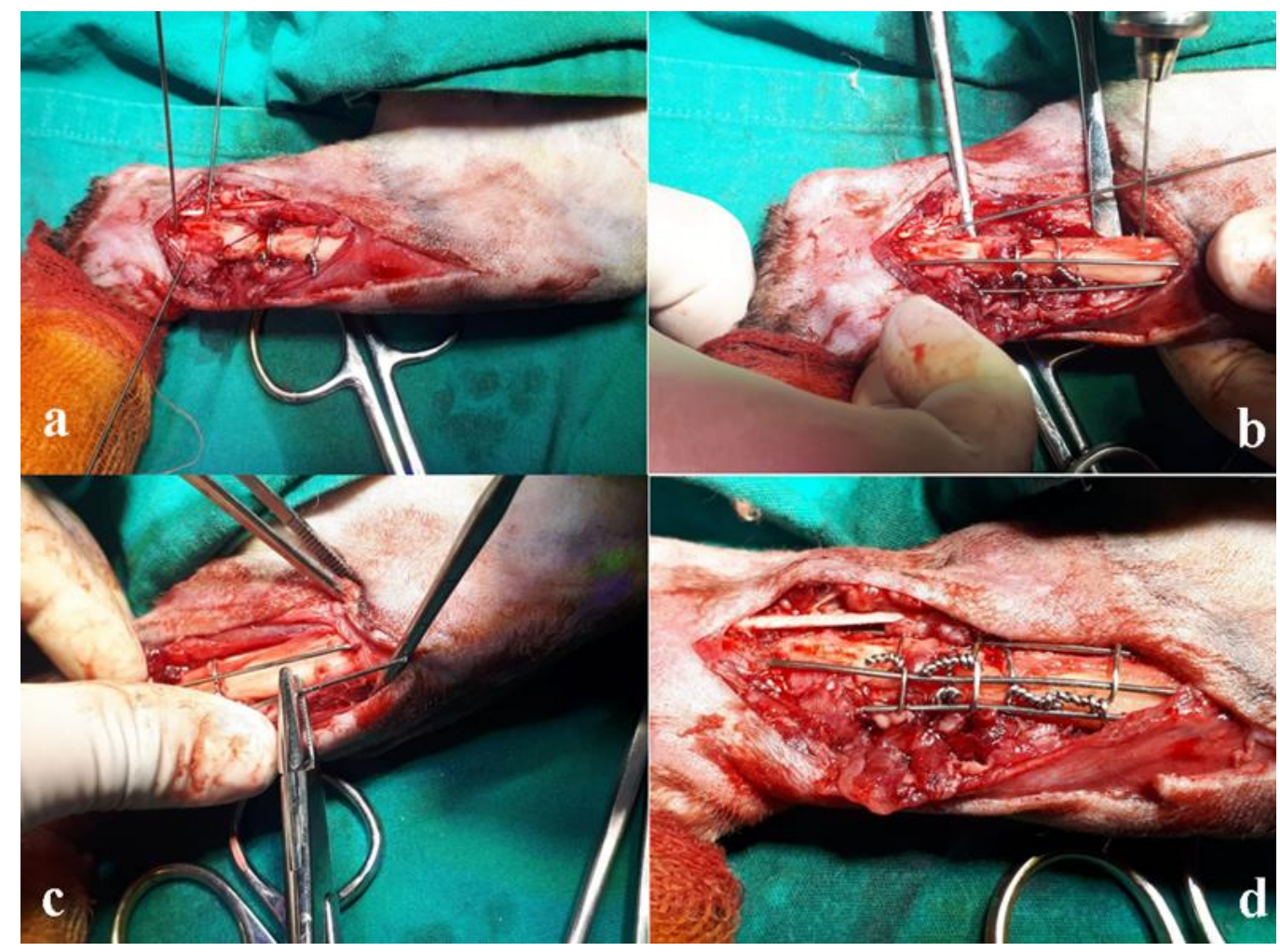

Figure 2. Application of the stabilisation technique with paraosseous clamp and cerclage to the tibia. a) transcortical application of the $\mathrm{K}$-wires to various surfaces of the fracture fragment, $\mathbf{b}$-c) bending the $\mathrm{K}$-wires to give a $\mathrm{U}$-shape, $\mathbf{d}$ ) paraosseous fixation with cerclage wires by passing the U-shaped K-wire through the holes opened in the upper fragment. 


\section{Results}

Nine of 14 cats various breeds and ages were male and 5 were female. The following breeds were included: 10 cross-breeds, 2 Ankara, 1 Persian and 1 Scottish Fold. The fracture localisation were included: 1 humerus, 4 radius-ulna, 2 proximal ulna fracture with dislocation of the radius head (Monteggia lesion), 2 femur, and 5 tibia. The clinical data of the cases are shown in Table 1.

In the follow-up examination on the postoperative $10^{\text {th }}$ day, no complications were observed in 13 cases. In case no 4 , angulation was observed in the fracture line, which was related to the metallic resistance of the $\mathrm{K}$-wires used in the application, and a revision operation was performed on this case. For this, the fracture line was reached with a routine procedure. A $3 \mathrm{~mm}$ Steinmann pin was applied to the femur with a retrograde technique from
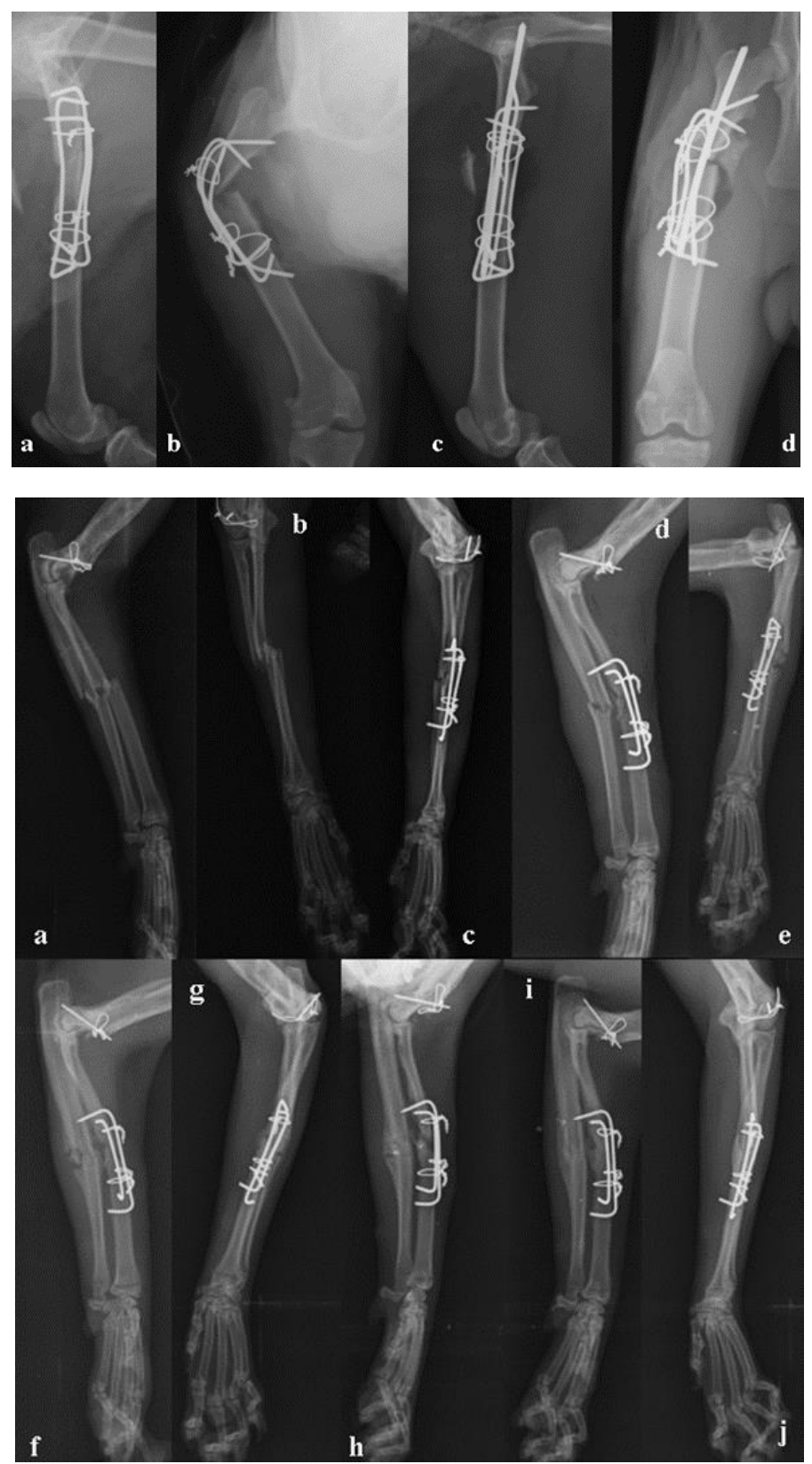

the medullary opening, from where the angulation of the fragments originated, and the fragments were re-aligned by correcting the angulated pins. The Steinmann pin was not advanced as far as the distal femur because of the narrowing of the medullar canal by the transcortically applied K-wires (Figure 3). The operation area was closed routinely and a supportive bandage was applied. This case could not be followed up after the postoperative $20^{\text {th }}$ day.

With the exception of case no 4, functional healing was obtained in all the other cases at the follow-up examination on the postoperative $45^{\text {th }}$ day, and all the cases were seen to be able to comfortably use the affected extremity. As the implants used were biocompatible, they were not removed but left on the bone after clinical healing (Figure 4 and Figure 5).
Figure 3. Craniocaudal ve mediolateral radiographs of case 4 of the fractured femur; a) postoperative $1^{\text {st }}$ day, b) postoperative $10^{\text {th }}$ day, c-d) postoperative $20^{\text {th }}$ day radiographs.
Figure 4. Craniocaudal ve mediolateral radiographs of case 6 of the fractured antebrachium; a-b) Immediate preoperative radiographs, c-d) postoperative $1^{\text {st }}$ day, e-f) postoperative $10^{\text {th }}$ day, $\left.\mathbf{g}-\mathbf{h}\right)$ postoperative $20^{\text {th }}$ day, $\mathbf{i}-\mathbf{j}$ ) postoperative $45^{\text {th }}$ day radiographs. 


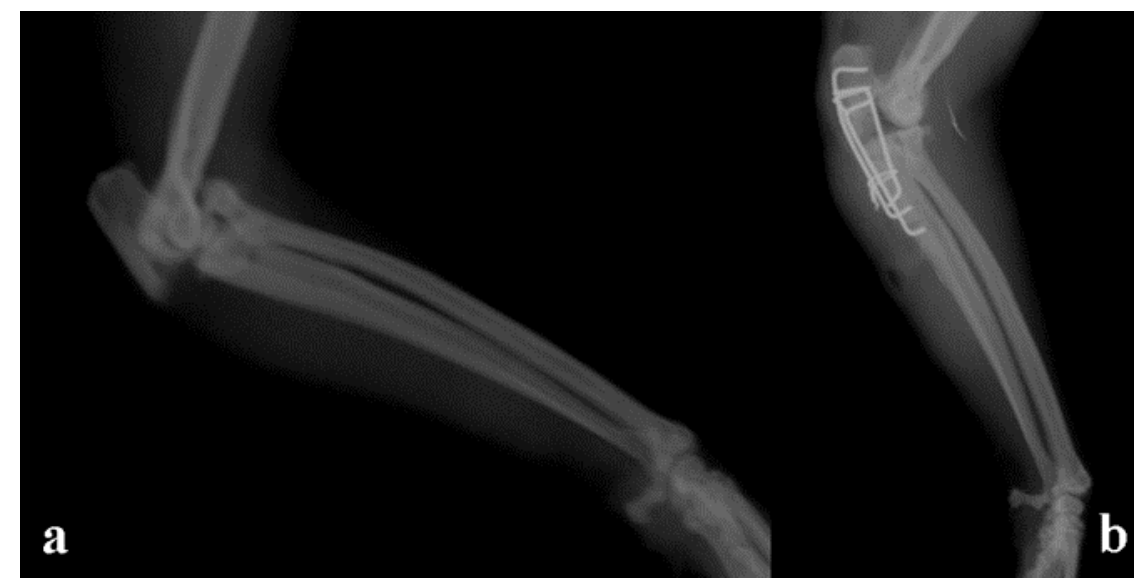

Figure 5. Mediolateral radiographs of case 9 of the fractured antebrachium; a) Immediate preoperative radiography, b) postoperative $30^{\text {th }}$ day radiograph.

\section{Discussion and Conclusion}

The method described here is a new method which provides rigid fixation in the treatment of long bone fractures. It can be used in the treatment of simple or fragmented fractures. For the application, the intact sections of both fragments must be of a length which can support a sufficient number of double cerclage wires for fixation of the clamps to the bone. This method is based on the attachment to each other of 3 double cerclage wires to form a paracortical belt (3). In previous studies that have reported the results of the paraosseous clamp and cerclage stabilisation technique, stabilisation has been obtained with double cerclage wires applied according to the method described with pins used in the treatment of various extremity long bone fractures. In addition, the use of a single layer cerclage wire in the application of paraosseous clamp and cerclage stabilisation technique has been reported to be successful in cats and small dog breeds with fractures of the antebrachium and tibia because of the small diameter and length of the bones (10). In the current study, the paraosseous clamp and cerclage stabilisation technique was applied to 14 cats of varying age and breed for fractures in the extremity long bones. Paraosseous stabilisation to the bone was obtained with $1.5 \mathrm{~mm}$ diameter $\mathrm{K}$-wires and $0.5 \mathrm{~mm}$ diameter cerclage wires bent to form a single layer around the K-wire and bone. In one of the current cases (case no 4), follow-up could not be continued after the postoperative $20^{\text {th }}$ day, and in the other 13 cases ( 1 humerus, 3 antebrachium, 2 Monteggia lesion, 2 femur and 5 tibia fractures), functional healing was obtained. According to these clinical healing results, this technique can be applied with single layer cerclage wire in the treatment of extremity long-bone fractures in cats.

Stress protection occurs when metal implants such as bone plate and screws are used in fracture treatment or joint replacement surgery. Although hard plates create rigid stabilisation in the fracture region, preserves contact between the fracture fragments and allows early weight-bearing and movement, resorption occurs as a result of the high rate of hardness of the implant and the reduced physiological burden of the bone (6). In previous studies, resorption has been reported in 7 of 20 fractures (7) and in 10 of 15 fractures (4). In a study by Manchi et al. (5), ulna resorption was determined in 2 cases and non-union in 1 ulna. The stress protection formed as a result of the rigid fixation created by the paraosseous clamp and cerclage stabilisation technique was concluded by the authors to have prevented the healing process of the ulna. In the 13 cases of the current study that completed the postoperative follow-up examinations, no complications of bone resorption, delayed union or non-union were observed. In addition to the fracture fixation provided by the $1.5 \mathrm{~mm}$ diameter $\mathrm{K}$ wires and $0.5 \mathrm{~mm}$ cerclage wires used in the application, union was stimulated by the micro-movement at the degree permitted between the fragments and it was thought that the physiological burden on the affected bone was not completely neutralised.

Manchi et al. (5) reported implant-associated complications in 4 of $17 \mathrm{dogs}$, and emphasised that healing was obtained as a result of the paraosseous clamp and cerclage stabilisation technique applied in the revision surgery of these cases. In the current study, implantrelated complications developed in one case (case no 4). On the postoperative 10th day clinical and radiological examinations, angulation was determined in the fragments with weight-bearing on the extremity, so revision surgery was performed on this case. In this operation, after reaching the femur, a $3 \mathrm{~mm}$ Steinmann pin was applied with the retrograde method from the medullar opening which had formed between the fragments because of angulation. At the same time, the $\mathrm{K}$-wires and cerclage wires applied paraosseously were corrected manually without removing them from the area. After routine closure of the operated area, the fragments were seen to 
have been sufficiently re-aligned on the radiograph. However, after this procedure, this case could not be followed up.

Reasons for preferring the paraosseous clamp and cerclage stabilisation technique in veterinary orthopaedic surgery are easy application together with internal fixation, especially in developing animals with large medullary canals, and it is a low-cost technique. It can be applied in the treatment of simple and fragmented fractures of extremity long bones. With the exception of case no 4, which could not be followed up, functional clinical healing was obtained in the other 13 cases with no complications.

Compared to other techniques defined for the treatment of long bone fractures, this is a new technique and data and study results in literature are extremely limited. Further studies would be able to contribute to this subject in respect of the advantages and disadvantages of the technique, overcoming complications originating from potential implant errors, and the evaluation of long-term results. As the functional healing results, including in unstable fractures, were correlated with low complication rates, the use of this technique in the treatment of long bone fractures is supported.

In conclusion, the paraosseous clamp and cerclage stabilisation technique provides successful results in the treatment of extremity long bone fractures in cats, and as the costs of application are lower compared to other treatment techniques, it can be considered to be a good alternative treatment method.

\section{Finacial Support}

This research received no grant from any funding agency/sector.

\section{Ethical Statement}

This study does not present any ethical concerns.

\section{Conflict of Interest}

The authors declared that there is no conflict of interest.

\section{References}

1. Bartolomaeus E, Niebauer GW, Schmiedmayer HB, et al (2007): Untersuchungen zum Biegeverhalten einer Parakortikalen-Klammer-Cerclage-Konfiguration im Vergleich $z u$ einer $3,5 \quad \mathrm{~mm}$ Dynamischen Kompressionsplatte. Wien Tierärztl Mschr, 94, 184-191.

2. Behrend A (2007): Biomechanische und klinische Studie zur chirurgischen Frakturversorgung langer Röhrenknochen der Katze. Mensch \& Buch Verlag, 68-69.

3. Fossum TW (2013): Radial and ulnar fractures. 1140-1154. In: Small Animal Surgery $4^{\text {th }}$ Edition. Mosby Inc, St. Louis.

4. Hamilton MH, Langley Hobbs SJ (2005): Use of the AO veterinary mini ' $T$ '-plate for stabilisation of distal radius and ulna fractures in toy breed dogs. Vet Comp Orthop Traumatol, 18, 18-25.

5. Manchi G, Brunnberg MM, Shahid M, et al (2017): Radial and ulnar fracture treatment with paraosseous clamp-cerclage stabilisation technique in 17 toy breed dogs. Vet Rec Open, 4, e000194.

6. Millis DL, Levine D (2014): Responses of Musculoskeletal Tissues to Disuse and Remobilization. 92-153. In: Canine Rehabilitation and Physical Therapy. 2nd Edition. Elsevier Inc. Saunders, Philadelphia.

7. Piras L, Cappellari F, Peirone B, et al (2011): Treatment of fractures of the distal radius and ulna in toy breed dogs with circular external skeletal fixation: a retrospective study. Vet Comp Orthop Traumatol, 24, 228-235.

8. Slunsky P, Halter L, Florczak S, et al (2017): Repair of a femoral fracture in a Congo African Grey parrot (Psittacus erithacus erithacus) with a paracortical-clamp-cerclage technique. J Zoo Wildl Med, 48, 1204-1209.

9. Şen İ, Sağlam M, Kibar B (2015): Kedilerde karşılașılan radius-ulna kırı̆̆ının sağaltım sonuçlarının klinik ve radyolojik değerlendirilmesi. Vet Hek Der Derg, 86, 25-33.

10. Wanivenhaus G (2001): Paraossäre Klammer-CerclageStabilisierung: eine Biologische osteosynthesemethode. Wien Tierärztl Mschr, 88, 123-128. 